\title{
Spatial Outcomes of Soft Tissue Sarcoma in Southern West Virginia
}

Frank H. Annie ${ }^{1}$, Christopher K. Uejio ${ }^{2}$, Sarah Embrey ${ }^{3}$

1. Cardiology, Charleston Area Medical Center, Charleston, USA 2. Geography, Florida State University, Tallahassee, USA 3. Pharmacy, University of Charleston School of Pharmacy, Charleston, USA

Corresponding author: Frank H. Annie, frank.h.annie@camc.org

\section{Abstract \\ Introduction}

Dioxins, polychlorinated biphenyls (PCBs), and 2,3,7,8-Tetrachlorodibenzodioxin (TCDDs) are persistent organic pollutants widely distributed in the food chain. For over 50 years, the Monsanto plant in Nitro, West Virginia, created dioxin waste while producing herbicides, Agent Orange (during the Vietnam War), and different forms of rubber. Recent and past literature has established a link between the Monsanto plant and increased cancer cases within the region. Soft tissue sarcoma is one of the few specific cancers that has been linked to dioxin exposure. This pilot study examined whether sarcoma cases were clustered or randomly distributed within Kanawha County, West Virginia over the years 2000 to 2013. We hypothesize that sarcoma cancer cases will be spatially clustered.

\section{Methods}

This study assessed the spatial distribution of cancer patients with addresses within the Nitro, West Virginia, and study area. The Charleston Area Medical Center shared soft tissue sarcoma $(n=97)$ cases from 2000 to 2013. An unweighted $\mathrm{K}$ function with confidence intervals ( 99 Monte Carlo permutations) and 10 distance at 2800 meters each band analyzed the distribution of cases.

\section{Results}

The results suggest that sarcoma cases are slightly clustered within the study area. The region also has a high concentration of chemical and industrial sites. The eighth distance band exhibited the greatest difference (11384), between the expected versus the observed K function.

\section{Conclusion}

The unweighted $\mathrm{K}$ function shows non-random clustering. Future studies could investigate possible associations to industrial, chemical, or other possible point source contamination within the study area.

Review began 10/26/2020 Review ended 11/03/2020 Published 11/12/2020

\section{(c) Copyright 2020}

Annie et al. This is an open access article distributed under the terms of the Creative Commons Attribution License CC-BY 4.0., which permits unrestricted use, distribution, and reproduction in any medium, provided the original author and source are credited.

\author{
Categories: Oncology \\ Keywords: dioxins, polychlorinated biphenyls (pcbs), k function
}

\section{Introduction}

Dioxins are a class of chemical by-products generated in various manufacturing processes, such as the production of rubbers and synthetic plastics. Dioxins are relatively stable chemicals that can degrade via sunlight and persist in the environment for several years [1]. Dioxin exposure research has been evolving since the first accident at the Monsanto plant in Nitro, West Virginia, in 1949. Subsequent accidents in West Germany in 1953 spurred more research into the long-term human health effects of dioxin exposure. From 1962 to 1970, the U.S. government commissioned companies such as Monsanto to produce Agent Orange, which created dioxin by-products; by the 1970s, the U.S. government had banned the use of the substance [1]. The primary avenue of human exposure is through contaminated foods [2]. Dioxins are divided into dioxin-like compounds and 2,3,7,8-Tetrachlorodibenzodioxin (TCDDs), which is one of the most toxic members of the dioxin family. Both dioxins and TCDDs are highly lipophilic and accumulate in human body fat [1].

Since 2003, the EPA and the National Academy of Sciences have attempted to improve the clarity of doseresponse curves and the toxicity of these chemicals in the general population. Exposure models attempt to explain the range of dosages that cause negative effects on human health [3-5]. Animal testing and several human trials have provided a benchmark for exposure. These studies were conducted to evaluate the longterm reproductive and developmental conditions that could occur with exposure to TCDDs over an extended period. Dose-response curve studies revealed that greater exposure to TCDD and polychlorinated biphenyls (PCBs) increased the odds of adverse health outcomes [6], which range from cancers to forms of multigenerational epigenetic changes and heart and neurological disorders [7]. 
Various authors have concluded that the evidence regarding the chronic effects of 2,3,7,8Tetrachlorodibenzo-p-dioxin (TCDD) exposures in humans is equivocal [8-10]. Cancer incidences are elevated in populations with relatively high exposures to TCDDs [11-12]. Studies on populations of concern have found increased rates of cancer among chemical workers and soldiers exposed to Agent Orange $[3,8,11,13]$.

This study updates findings with several historical studies of accidental TCDD releases in 1949, 1962, and 1971 in Nitro, West Virginia $[3,8,11,13]$.

Most cancer cluster studies do not find an association with a point source exposure (i.e., a contaminant or an industrial exposure site). However, it should be noted that only two studies confirm clustering of childhood cancer as a result of environmental contaminants; the two related sites are in Woburn, Massachusetts, and Dover Township, New Jersey [14]. The Woburn, Massachusetts, report examined six cases of childhood leukemia from 1969 to 1979. These cases were geographically clustered, and arsenic was theorized as the possible point source for leukemia cases. Geographic data analysis and spatial statistics investigated the relationship of cancer clusters in regions and possible sources.

Soft tissue sarcoma is an extremely rare cancer subtype that affects 6.26 men and 4.60 women per 100,000 per year. Over the 13-year study period, 60 cases were observed; this is above the national average of these cases in the same studied time frame [15]. This type of sarcoma is recognized as dioxin sensitive within the established literature [16-17].

\section{Materials And Methods}

This study assessed the spatial distribution of cancer patients with addresses in the Nitro, West Virginia, study area and all sarcoma patients recorded in the Charleston Area Medical Center and affiliated David Lee Cancer Center cancer registry from 2000 to 2013. The study excluded patients younger than 18 at diagnosis, which is a notable study limitation since some types of soft tissue sarcoma occur almost exclusively in pediatric populations [1]. The home billing address of each patient was geocoded using ArcGIS 10.6 to latitude and longitude. The ESRI Street Map geocoder reported an accuracy of 100\%.

This study examines whether soft tissue sarcoma cases are clustered compared to complete spatial randomness. An unweighted Ripley's K function with a maximum distance band of 26 miles quantified the degree of spatial clustering. In the equation, $\mathrm{K}(\mathrm{h})$ is the expected number of events inside the radius (h). The area is described as A, and the number of observed events is described as $\mathrm{N}$. The distance function is illustrated as dij, which is the distance between the events of $\mathrm{i}$ and $\mathrm{j}$. The $\mathrm{K}$ function did not artificially adjust for edge corrections which set wi to 1 . Monte Carlo simulations created a 99\% null confidence envelope, using 99 permutations as confidence bands.

\section{Results}

Table 1 and Figure 1 present the $\mathrm{K}$ function relationship based on the 10 distance bands. The observed $\mathrm{K}$ was significantly above the expected $\mathrm{K}$ across all 10 distance bands. The eighth distance band exhibited the largest difference (11384), between the expected versus the observed K function. Although evidence seems to support the occurrence of clustering within the Nitro and Saint Albans areas, further epidemiological and spatial studies are required. As this is designed as a pilot study, the supposed distribution of soft tissue sarcoma may be influenced by other factors that were not directly studied in the Charleston Area Medical Center service area. 


\section{Cureus}

\begin{tabular}{|c|c|c|c|c|c|}
\hline OBJECTID * & ExpectedK & ObservedK & DiffK & LwConfEnv & HiConfEnv \\
\hline 1 & 2800.77355 & 8143.252776 & 5342.479226 & 1578.908991 & 4630.270075 \\
\hline 2 & 5601.5471 & 13545.530075 & 7943.982975 & 4789.068085 & 7200.932918 \\
\hline 3 & 8402.320651 & 17835.382795 & 9433.062145 & 7405.739613 & 10035.70254 \\
\hline 4 & 11203.094201 & 21124.362583 & 9921.268382 & 10401.643441 & 12904.623223 \\
\hline 5 & 14003.867751 & 24255.66016 & 10251.792409 & 13172.303163 & 15582.479928 \\
\hline 6 & 16804.641301 & 27709.740328 & 10905.099026 & 15502.281352 & 18222.5525 \\
\hline 7 & 19605.414852 & 30485.62124 & 10880.206388 & 18277.19296 & 20791.299968 \\
\hline 8 & 22406.188402 & 33790.127984 & 11383.939582 & 21065.273341 & 23450.918198 \\
\hline 9 & 25206.961952 & 36342.355698 & 11135.393746 & 23746.707235 & 26476.754947 \\
\hline 10 & 28007.735502 & 38668.767368 & 10661.031865 & 26192.76295 & 28993.515727 \\
\hline
\end{tabular}

TABLE 1: Output of Ripley's K-Function

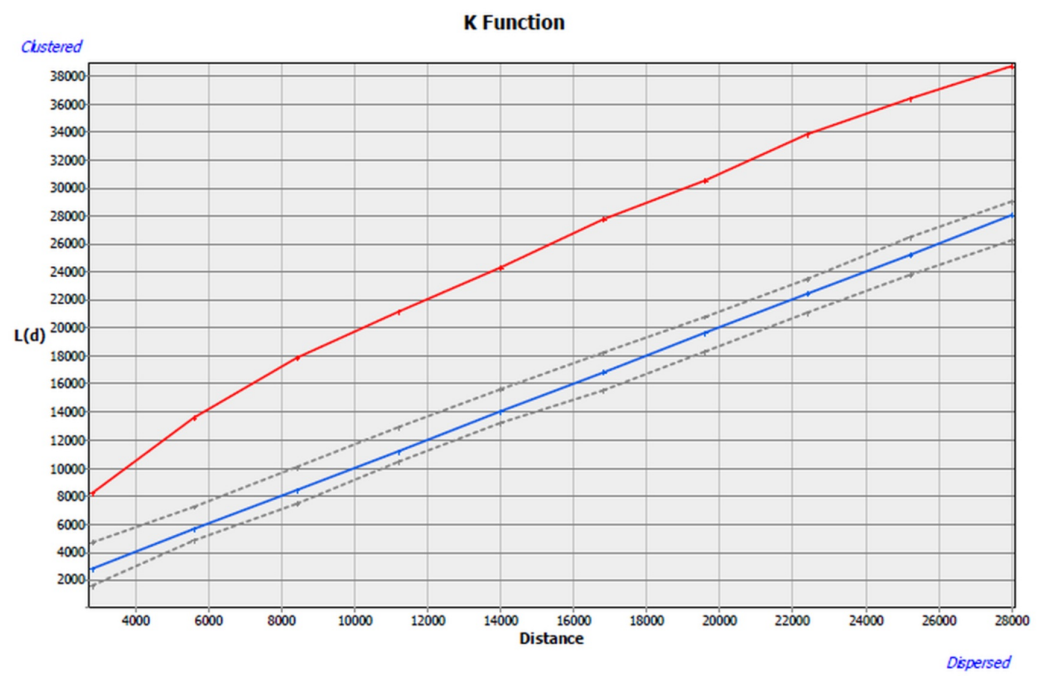

FIGURE 1: K-Function Graphic

\section{Discussion}

Our study suggests that there might be a suggestive relationship of clustering within the service area of the Charleston Area Medical Center. Studies such as this are necessary to understanding whether there is any association between soft tissue sarcoma and point source contamination. Soft tissue sarcoma represents less than $1 \%$ of total cancers diagnosed per year $[15,18]$. Previous studies have supported a connection between soft tissue cancers and dioxin-based exposure [16-17]. Other studies in the area have established relationships between dioxin and low birth weight as an effect of production of dioxin-based exposure from 1955-1969 [19]. Exposure and production occurred decades prior to this study that could establish a possible continued environmental contaminant. Further research in the region has established a possible spatial relationship to congenital heart defects as a result of chemical and coal extraction sites [20]. Point source contamination as described in this study describes a statistical significant relationship to potential points of concern in the region in relation to congenital heart defects. Other disease states have also been explored as well such as Müllerian anomalies within the obstetric population in the same region [21]. The obstetric population showed a similar statistical relationship between Müllerian anomalies and EPA regulated facilities. Over all literature in the region shows a suggestive relationship with differing point source contamination and possible exposure which requires further research. 


\section{Conclusions}

Based on the findings of this study, more research is necessary. Moreover, many confounders may not be represented in the data. The data's accuracy was also limited to the documentation in the electronic health records. As the half-life of dioxin is over 11 years, the most impactful future direction for this project would be to analyze blood samples from the 97 individual cases to quantitatively determine their exposure to dioxins. This testing could more definitely link dioxin exposure to the occurrence of these cancers. Once this information is gathered, a more thorough spatial analysis can be conducted to evaluate and explain any potential variables and establish controls within the population, which could assist in verifying environmental causality.

\section{Additional Information \\ Disclosures}

Human subjects: Consent was obtained by all participants in this study. CAMC/WVU issued approval NA. NA. Animal subjects: All authors have confirmed that this study did not involve animal subjects or tissue. Conflicts of interest: In compliance with the ICMJE uniform disclosure form, all authors declare the following: Payment/services info: All authors have declared that no financial support was received from any organization for the submitted work. Financial relationships: All authors have declared that they have no financial relationships at present or within the previous three years with any organizations that might have an interest in the submitted work. Other relationships: All authors have declared that there are no other relationships or activities that could appear to have influenced the submitted work.

\section{References}

1. Gibbs LM: Dying from Dioxin: A Citizen's Guide to Reclaiming Our Health and Rebuilding Democracy . Black Rose Books Ltd, 1995. 10.5860/CHOICE.33-5743

2. Lorber M, Patterson D, Huwe J, Kahn H: Evaluation of background exposures of Americans to dioxin-like compounds in the 1990s and the 2000s. Chemosphere. 2009, 77:640-651. 10.1016/j.chemosphere.2009.08.016

3. Aylward L, Brunet R, Carrier G, et al.: Concentration-dependent TCDD elimination kinetics in humans: toxicokinetic modeling for moderately to highly exposed adults from Seveso, Italy, and Vienna, Austria, and impact on dose estimates for the NIOSH cohort. J Expo Anal Environ Epidemiol. 2005, 15:51-65. 10.1038/sj.jea.7500370

4. Emond C, Michalek JE, Birnbaum LS, DeVito MJ: Comparison of the use of a physiologically based pharmacokinetic model and a classical pharmacokinetic model for dioxin exposure assessments. Environ Health Perspect. 2005, 113:1666-1668. 10.1289/ehp.8016

5. Simeonov L: Environmental epidemiology as a method for risk assessment of chemical pollution . In: Exposure and Risk Assessment of Chemical Pollution -- Contemporary Methodology. Simeonov LI, Hassanien MA (ed): Springer, Dordrecht; 2009. 227-232.

6. Windal I, Denison MS, Birnbaum LS, Wouwe NV, Baeyens W, Goeyens L: Chemically activated luciferase gene expression (CALUX) cell bioassay analysis for the estimation of dioxin-like activity: critical parameters of the CALUX procedure that impact assay results. Environ Sci Technol. 2005, 39:7357-7364. 10.1021/es0504993

7. Weisglas-Kuperus N, Patandin S, Berbers GA, Sas TC, Mulder PG, Sauer PJ, Hooijkaas H: Immunologic effects of background exposure to polychlorinated biphenyls and dioxins in Dutch preschool children. Environ Health Perspect. 2000, 108:1203-1207. 10.1289/ehp.001081203

8. Andersson M, Ottesen RT: Levels of dioxins and furans in urban surface soil in Trondheim, Norway . Environ Pollut. 2008, 152:553-558. 10.1016/j.envpol.2007.07.008

9. Egeland GM, Sweeney MH, Fingerhut MA, Wille KK, Schnorr TM, Halperin WE: Total serum testosterone and gonadotropins in workers exposed to dioxin. Am J Epidemiol. 1994, 139:272-281. 10.1093/oxfordjournals.aje.a116994

10. Gilpin RK, Wagel DJ, Solch JG: Production, distribution, and fate of polychlorinated dibenzo-p-dioxins, dibenzofurans and related organohalogens in the environment. In: Dioxins and Health. Schecter A, Gasiewicz T (ed): John Wiley \& Sons, Inc, Hoboken, NJ; 2003.

11. Longnecker MP, Ryan JJ, Gladen BC, Schecter AJ: Correlations among human plasma levels of dioxin-like compounds and polychlorinated biphenyls (PCBs) and implications for epidemiologic studies. Arch Environ Health. 2000, 55:195-200. 10.1080/00039890009603406

12. Olie K, Addink R, Schoonenboom M: Metals as catalysts during the formation and decomposition of chlorinated dioxins and furans in incineration processes. J Air Waste Manag Assoc. 1998, 48:101-105. 10.1080/10473289.1998.10463656

13. Alaluusua S, Lukinmaa PL: Developmental dental toxicity of dioxin and related compounds-a review . Int Dent J. 2006, 56:323-331. 10.1111/j.1875-595x.2006.tb00336.x

14. Costas K, Knorr RS, Condon SK: A case-control study of childhood leukemia in Woburn, Massachusetts: the relationship between leukemia incidence and exposure to public drinking water. Sci Total Environ. 2002, 300:23-35. 10.1016/s0048-9697(02)00169-9

15. Toro JR, Travis LB, Wu HJ, Zhu K, Fletcher CDM, Devesa SS: Incidence patterns of soft tissue sarcomas, regardless of primary site, in the surveillance, epidemiology and end results program, 1978-2001: an analysis of 26,758 cases. Int J Cancer. 2006, 119:2922-2930. 10.1002/ijc.22239

16. Hardell L, Sandström A: Case-control study: soft-tissue sarcomas and exposure to phenoxyacetic acids or chlorophenols. Br J Cancer. 1979, 39:711-717. 10.1038/bjc.1979.125

17. Hardell L, Eriksson M, Degerman A: Meta-analysis of four Swedish case-control studies on exposure to 


\section{Cureus}

pesticides as risk-factor for soft-tissue sarcoma including the relation to tumor localization and histopathological type. Int J Oncol. 1995, 6:847-851. 10.3892/ijo.6.4.847

18. Spiguel A: Soft tissue sarcomas. In: Orthopaedic Oncology. Cancer Treatment and Research. Peabody T, Attar S (ed): Springer, Cham; 2014. 162:203-223. 10.1007/978-3-319-07323-1_10

19. Annie FH, Uejio CK, Embrey S, Tager A: The effect of dioxin on low birth weight in southern west Virginia between 1955 to 1969 (PREPRINT). medRxiv. 2020, 10.1101/2020.09.22.20199059

20. Viglianco K, Annie F, Seybold D, Riley M, Calhoun B, Andrews K: Congenital heart defects in West Virginia: preliminary findings from an ecological study of effects of an industrial watershed on increased incidence. Reprod Toxicol. 2019, 90:62-67. 10.1016/j.reprotox.2019.08.011

21. Schaible B, Annie F, Seybold D, Calhoun BC: Ecological study of effects of industrial watershed on Müllerian anomalies in an obstetric population. Ecotoxicol Environ Saf. 2020, 202:110819.

10.1016/i.ecoenv.2020.110819 